\title{
P-piller, migrene og hjerneinfarkt
}

\author{
Nyere studier taler for at en mulig assosiasjon mellom hjerneinfarkt og lavdose p-piller er fraværende \\ eller uten klinisk relevans. Dette ser også ut til å gjelde normotensive, ikke-røykende kvinner med migrene, \\ både med og uten aura.
}

Økt risiko for tromboemboliske komplikasjoner ved bruk av p-piller har vært kjent i mange år. Redusert innhold av østrogen er assosiert med mindre risiko for dyp venetrombose eller lungeemboli. Dessuten er det gode holdepunkter for at gestagenkomponenten er av betydning for venøse tromboembolier (1). Fortsatt er det flere uavklarte spørsmål rundt bruk av p-piller. Det gjelder særlig risikoen for hjerneinfarkt ved bruk av p-piller hos kvinner med eller uten migrene. Vi mener nyere studier taler for at dagens p-piller med lavt innhold av østrogen er forbundet med liten eller ingen $ø k t$ risiko for hjerneinfarkt (2).

\section{P-piller og hjerneinfarkt}

Mange studier har funnet assosiasjon mellom p-piller og arterielle embolier eller tromboser (både hjerneinfarkt og hjerteinfarkt). Disse komplikasjonene er spesielt fryktet på grunn av høy morbiditet og mortalitet. I 1975 ble det publisert en artikkel som viste at høydose p-piller ( $\geq 50 \mu \mathrm{g} ø$ øsrogen) var assosiert med en fire ganger $ø \mathrm{kt}$ risiko for hjerneinfarkt (3). En stor WHOstudie viste også økt risiko for hjerneinfarkt ved høydose p-piller, men ingen økt risiko ved p-piller som inneholdt mindre enn 50 $\mu \mathrm{g}$ østrogen (4). I en stor amerikansk studie fant Petitti og medarbeidere heller ikke økt risiko for hjerneinfarkt ved lavdose p-piller (5). Fra Danmark fant Lidegaard og medarbeidere at gjennomsnittlig relativ risiko for hjerneinfarkt og hjerteinfarkt ved bruk av p-piller med østrogeninnhold på $20 \mu \mathrm{g}$ var 0,9-1,7, avhengig av gestagentype (6). Risikoen var litt høyere ved høyere østrogeninnhold. Røyking dobler risikoen for hjerneinfarkt. Det er mulig røyking øker risikoen for hjerneinfarkt hos p-pillebrukere med migrene utover dette (7).

\section{Migrene og hjerneinfarkt}

Flere studier har vist at migrene og særlig migrene med aura ser ut til å være assosiert med økt risiko for hjerneinfarkt (7). Den økte risikoen har særlig vært forbundet med høydose p-piller, men absolutt risiko er lav (2). Ved tolkningen av assosiasjonen mellom migrene og hjerneinfarkt er det flere fallgruver. Migreneaura som ofte forekommer uten hodepine, kan en sjelden gang vare så lenge at de nevrologiske symptomene (synsforstyrrelser, lammelser, afasi eller parestesier) feiltolkes som hjerneinfarkt (persisterende eller prolongert aura). Dette er en mulig grunn til at migrene med aura feilaktig har vært assosiert med økt risiko for hjerneinfarkt. Forekomsten av langvarig migreneaura er usikker, men en fersk studie blant norske nevrologer kan tyde på at prevalensen av migreneaura trolig er høyere enn tidligere antatt (8). Ut fra dette mener vi at også forekomsten av langvarig migreneaura kan være hyppigere enn det man har gått ut ifra til nå. På grunn av høy sensitivitet for akutt hjerneinfarkt sammenliknet med CT vil diffusjons-MR redusere feildiagnostisering av langvarig migreneaura som hjerneinfarkt (9).

\section{P-piller og migrene}

Kombinasjonspiller ser ut til å være forbundet med økt forekomst av migreneanfall både med og uten aura, fordi fravær av østrogen i pillene den siste uken av syklus kan

\section{«Vi mener nyere studier taler for at dagens p-piller med lavt innhold av østrogen er forbundet med liten eller ingen økt risiko for hjerne- infarkt»}

utløse migrene (2). Dette er trolig et mindre problem med lavdose p-piller (2). At p-piller øker frekvensen av migrene med aura som en sjelden gang kan være langvarig, bidrar derfor potensielt til assosiasjonen mellom p-piller og hjerneinfarkt, men igjen kan dette hos noen skyldes feildiagnostisering av langvarig migreneaura som hjerneinfarkt. Bruken av p-piller hos pasienter med migrene og aura er derfor fortsatt kontroversiell (3).

I Hordaland er det gjort en populasjonsbasert studie av pasienter i alderen 15-49 år med hjerneinfarkt i tidsrommet 1988-97 (10). Bruken av p-piller var lavere hos kvinner med hjerneinfarkt enn hos aldersparede kontrollpersoner uten hjerneinfarkt $(\mathrm{n}=41(43 \%)$ versus $\mathrm{n}=58(57 \%))$ (upubliserte data fra Næss og medarbeidere (10)). Det var ingen forskjell mellom pasientene og kontrollpersonene i bruk eller ikke bruk av p-piller og forekomsten av migrene.
I 2011 publiserte vi en studie som viste statistisk signifikant nedgang $\mathrm{i}$ insidensen av hjerneinfarkt hos kvinner $i$ alderen 15-30 år i Hordaland, fra 16 tilfeller i perioden 1988-97 (3,3 per 100000 per år) til 0 tilfeller i perioden 2006-10 (0 per 100000 per år) (11). Vi tror nedgangen delvis kan skyldes bruk av lavdose p-piller og mindre feildiagnostisering av langvarig migreneaura fordi de fleste med mulig hjerneinfarkt i perioden 2006-10 ble undersøkt med diffusjons-MR. En tilsvarende reduksjon ble ikke sett hos menn.

\section{Konklusjon}

De store internasjonale studiene med lavdose p-piller taler for at risikoen for hjerneinfarkt er liten eller i best fall fraværende hos normotensive, ikke-røykende kvinner med eller uten migrene (inkludert migrene med aura) (2). Våre studier fra Hordaland støtter hypotesen om at lavdose p-piller ikke er assosiert med hjerneinfarkt enten kvinnene har migrene eller ikke. Teoretisk er det mulig at den rapporterte assosiasjonen mellom hjerneinfarkt og p-piller skyldes at østrogenbortfall de siste dagene av syklus fører til økt forekomst av langvarig migreneaura som feiltolkes som hjerneinfarkt. Etter vårt skjønn kan derfor lavdose p-piller også brukes hos normotensive, ikke-røykende kvinner med migrene med eller uten aura. Hos mange kvinner med syklusavhengige migreneanfall kan minipillen være gunstig som migreneprofylakse.

\section{Halvor Næss}

halvor.ness@helse-bergen.no Ole Erik Iversen

Halvor Næss (f. 1957) er spesialist i nevrologi og indremedisin. Han er overlege på Slagenheten ved Haukeland universitetssykehus. Forfatter har fylt ut ICMJE-skjemaet og oppgir ingen interessekonflikter.

Ole Erik Iversen (f. 1945) er spesialist i fødselshjelp og kvinnesykdommer, overlege ved Kvinneklinikken, Haukeland universitetssykehus og professor ved Det medisinsk-odontologiske fakultet, Universitetet i Bergen.

Forfatter har fylt ut ICMJE-skjemaet og oppgir følgende interessekonflikter: Han sitter i Scientific Advisory Board i Merck for 2. generasjons HPV-vaksiner og har mottatt foredragshonorar fra Bayer og MSD. 


\section{Litteratur}

1. Lidegaard O, Løkkegaard E, Svendsen AL et al. Hormonal contraception and risk of venous throm boembolism: national follow-up study. BMJ 2009; 339: b2890.

2. Calhoun A. Combined hormonal contraceptives: is it time to reassess their role in migraine? Headache 2012; 52: 648-60.

3. Oral contraceptives and stroke in young women Associated risk factors. JAMA 1975; 231: 718-22.

4. Ischaemic stroke and combined oral contraceptives: results of an international, multicentre, case-control study. WHO Collaborative Study of Cardiovascular Disease and Steroid Hormone Contraception. Lancet 1996; 348: 498-505.

5. Petitti DB, Sidney S, Bernstein A et al. Stroke in users of low-dose oral contraceptives. N Engl J Med 1996; 335: 8-15.

6. Lidegaard $\mathrm{O}$, Løkkegaard E, Jensen A et al. Thrombotic stroke and myocardial infarction with hormonal contraception. N Engl J Med 2012; 366: 2257-66.

7. Chang $C L$, Donaghy M, Poulter N. Migraine and stroke in young women: case-control study. BMJ 1999; 318: 13-8.

8. Alstadhaug KB, Hernandez A, Naess $\mathrm{H}$ et al. Migraine among Norwegian neurologists. Headache 2012: 52: 1369-76.

9. Naess H, Brogger JC Jr, Idicula T et al. Clinical presentation and diffusion weighted MRI of acute cerebral infarction. The Bergen Stroke Study. BMC Neurol 2009; 9: 44

10. Naess H, Nyland HI, Thomassen L et al. Etiology of and risk factors for cerebral infarction in young adults in western Norway: a population-based case-control study. Eur J Neurol 2004; 11: 25-30.

11. Naess H, Fromm A, Iversen OE et al. Decline of arterial cerebral infarction among young women: the Bergen Stroke Study. Vasc Health Risk Manag $2011 ; 7: 81-4$

Mottatt 8.1. 2013, første revisjon innsendt 3.2. 2013, godkjent 20.2. 2013. Medisinsk redaktør Siri Lunde.

Publisert først på nett. 